\title{
Politeness Maxims Used by English Students Program Study at STKIP Tama Siswa Bima
}

\author{
Annisah $^{1}$, Waliyudin' ${ }^{2}$, Ramli, ${ }^{3}$ Nurbaya $^{4}$ \\ ${ }^{1234}$ STKIP Taman Siswa Bima \\ Email: Annisahnukman@gmail.com, waliyudinkhalik@gmail.com, ramlialfatih88@gmail.com \\ nurbaya92@gmail.com
}

\begin{abstract}
Politeness Maxims Used by English Students Program Study at STKIP Taman Siswa Bima. The aims of this research are to find out the types and the function of most dominant types of politeness maxim used by students in classroom interaction during learning process. The subject of this research is the students of English Program Study, the STKIP Taman Siswa Bima. This research used descriptivequalitative method. Samples on this research consist of 25 students. To collect the data video recorded was used to record the students' utterance and interaction in the class. The students' utterances transcribed and analyze based on types and function of most dominant type's politeness maxim. The result of this research there were six types of politeness maxim applied in classroom interaction, they were Tact Maxims, Generosity Maxim, Approbation maxim, Agreement Maxim, Sympathy Maxim, Modesty Maxim. The dominant types were used by students is tact maxim, and it plays several functions such as declarative function, interrogative function, imperative function, the apology function
\end{abstract}

Keywords: Politeness, Maxim.

\section{PENDAHULUAN}

Communication is very important in human life. Communication can be defined as the process of transmitting information and common understanding from one person to another. In other side, communication means as the process of transfer an idea to one or more recipient, with the intention of changing behavior.

According to I Ketut Seken (2011), language is vehicle of social interaction between members of a community. As such, it cannot separate from the community and culture in which it is used by people. Sociocultural aspect are crucial components of the communicative context, which affect the meaning of the speech acts conveyed, the communicative intent behind the expressed utterances, relationship between utterances, and how acts are organized within events and events within communicative situation. Those are covered in politeness of communication.

Politeness is one of social rules in making communication. Politeness is developed by society in order to reduce friction in personal interaction. There are three rules to apply politeness they are formality, hesitancy, and equally or solidarity.

I ketut Seken (2011) defined politeness as the speaker language expression that respect the rights of the addressee or other participant in an interaction. Politeness is shown by expressing something that makes the addressee feel he/she is important and/or by showing appreciation for what the addressee has said or done.

Politeness is play important role in social communication because it is a manner of language associated with smooth interaction in social life. There are three factors influenced the application of politeness in communication or interaction, such as age, gender, and context of situation. People can speech varies in different ages, also for gender. Different gender can served different way in speech, and the different situation can makes different ways for someone to say something to other.

Aulia (2019) said Politeness is needed in every particular life. Politeness is about keeping good relation with your listener or reader. Politeness is important because it is showing the 
listener or reader that we value and respect them, and changing or softening what we say so is not to be forceful.

According to Imanuel Kamlasi (2017), there are six principles maxim of politeness such as; a) Tact Maxims, this maxim refers minimize cost other and minimize the benefit to other. In this maxim speaker minimizes the cost (correspondingly maximizes the benefit) to the listener, b) Generosity Maxim, refers to minimize benefit to self and maximize cost to self. This is magnanimous maxim which requires the speaker to respect other. The respect occur when the speaker can minimize the benefit for him selves and maximize the benefit for other, c) Approbation maxim is minimizing dispraise of other and maximize praise of other. It's only applicable in illocutionary functions as "expressive, e.g. thanking, congratulating, pardoning, blaming, praising, condoling, boasting, complaining, claiming, and reporting. It means this maxim is used to avoid saying unpleasant things about others to the hearer, d) Agreement Maxim refers to minimize the expression of disagreement between self and other and maximize the expression of agreement between self and other. The disagreement in this maxim is usually expressed by regret or partial agreement, e) Sympathy Maxim refers to minimize antipathy between self and other and maximize sympathy between self and other. In this case, the achievementbeing reached by other, for instance, must be appreciated and evaluated. On other hand, the calamity happens to other must be given sympathy orcondolences, f) Modesty Maxim refers to minimize praise of self and maximize dispraise of self. Both approbation maxim and modesty maxim concern with the degree of good or bad evaluation of other or self that is performed by the speaker. However, this maxim usually occurs in apologizing something.

In the field of education and language teaching, politeness issued had also been observed. Yuka's (2009) research revealed that positive politeness plays important roles when performing good interpersonal relationship. Jiang's (2010) study had proved that being polite in the class can function as a way to "promote" the mutual understanding and harmonious relationship between teacher and students.

Most of those politeness studies above investigated the use of languages to express or to show politeness. It is also important to look more thoroughly on how politeness behaviours and strategies are perceived. In other words, studies on how people think about politeness are also important. Murni (2018) argues that "politeness strategies vary from language to language, from culture to culture". Graham (2007) also states that "perception of (im)politeness vary from one individual to one another and there are multiple gradations of more- or less-(im)polite behaviour". This means that politeness will be perceived differently in different situations. In this study, students could reveal different perspectives about politeness practices in the class.

Referring to these phenomena, the researcher considered that studies on how politeness is perceived are important. For this purpose, this paper is directed to find out types of politeness maxim used by English Students, and what is the function of most dominant types are used by English students to create effective communication and interaction in the class.

\section{METODE}

This paper is a descriptive-qualitative study, which was intended to collect, analyze, and interpret several data which were related to particular phenomena, that is types of politeness maxim, and the function of most dominant types used in classroom interaction.

The study was conducted at STKIP Taman Siswa Bima. This campus was selected because it only campus conducted English Program Study in Bima area. Participant of this research were the undergraduate students of English Program Study STKIP Taman Siswa Bima, academic years 2019/2020, which consist of 25 students.

To collect data the researcher used video recorded. The video used to record the interaction and utterances of students. 


\section{HASIL DAN PEMBAHASAN}

This part displays the data of types and dominant types function of students' politeness maxim in class interaction.

Tabel 1. Types of politeness maxim used by students in classroom interaction

\begin{tabular}{|c|c|c|c|c|c|}
\hline \multirow[t]{2}{*}{ No } & \multirow{2}{*}{$\begin{array}{c}\text { Types of } \\
\text { Politeness } \\
\text { Maxim }\end{array}$} & \multicolumn{3}{|c|}{$\begin{array}{c}\text { Students interaction record } \\
\text { by video }\end{array}$} & \multirow{2}{*}{$\begin{array}{l}\text { Total } \\
\text { freque } \\
\text { ntly of } \\
\text { use }\end{array}$} \\
\hline & & $\begin{array}{c}\text { Video } \\
1\end{array}$ & $\begin{array}{c}\text { Video } \\
2\end{array}$ & $\begin{array}{c}\text { Video } \\
3\end{array}$ & \\
\hline 1 & Tact Maxim & 19 & 34 & 15 & 68 \\
\hline 2 & $\begin{array}{l}\text { Generosity } \\
\text { Maxim }\end{array}$ & - & - & 1 & 1 \\
\hline 3 & $\begin{array}{l}\text { Approbation } \\
\text { Maxim }\end{array}$ & 6 & 3 & 5 & 14 \\
\hline 4 & $\begin{array}{l}\text { Agreement } \\
\text { Maxim }\end{array}$ & 3 & 5 & 2 & 10 \\
\hline 5 & $\begin{array}{l}\text { Modesty } \\
\text { Maxim }\end{array}$ & 1 & - & - & 1 \\
\hline 6 & $\begin{array}{l}\text { Sympathy } \\
\text { Maxim }\end{array}$ & 2 & - & - & 2 \\
\hline
\end{tabular}

From the data in table 1 , the most dominant types of politeness maxim used by students in classroom interaction were tact maxim with 68 total frequently of used, and approbation maxim with 14 total frequently of used, then agreement maxim with 10 total frequently of used.

According to Tri Rina Budiawati (2018) tact maxim plays several functions such as; a) declarative function. This is used to declaring information, expressing congratulation, and declaring a warning, b) interrogative function, it used to requesting an answer, asking for sincerity, asking permission, asking for reason, asking for information and asking for opinions, c) Imperative function, refers to enjoy, prohibit, ask for help, and suggest, d) The apology function can be use from the word "sorry" as the approbation maxim, in evoked the spirit of students in teaching and learning process with the factor of context of situation and participant that happened in classroom interaction.

The first important finding from this research is about the roles of politeness in the class. Students are not totally understood with the used of politeness in interaction, and they were not have much interaction in the class. So the frequently of the use of politeness maxim was less.

This study also showed that classroom as the setting of communication especially between lecture and students. The lecture becomes more dominant in the class, while students become passive, and not expressive.

\section{KESIMPULAN}

This paper has explored the types and function of dominant types of politeness maxim. Findings of this study are beneficial input for teacher and students in order to create effective classroom interaction. This study also show if each students were having different perception on politeness, it can be conclude from the different types of utterance they used to express their politeness.

\section{SARAN}

In order to maintain the politeness in the class, teacher need to apply some kinds of rituals of expressions such as greetings, apologies, thanks, and address term. The used of those expressions were to build good relation between teachers and students, and to educate the students about politeness behavior.

\section{UCAPAN TERIMA KASIH}

I would like to thank to Students of English Program Study the STKIP Taman Siswa Bima, Academic Years 2019/2020, who had participated as sample of this study.

\section{DAFTAR PUSTAKA}

A.Yuka's. (2009). Positive politeness Strategies in Oral Communication I Textbooks. The Economic Journal of Tokasaki City University of Econimics. Vol. 52. pp. $59-70$

Aulia Arifani Miladesia. (2019). The Use of Politeness by Students During Discussion Session in EFL Class. Thesis. The State Institute of Islamic Studies of Bengkulu.

I Ketut Seken. (2011). Some Notes on Linguistic Politeness and Its Relation to Second Language Teaching. Journal Lingua Scienta. Vol. 18. No 1. ISSN

Imanuel Kamlasi. (2017). the Positive Politeness in Conversations Performed by the Students of English Study Program of Timor University. Journal of English Language, Literature, and Teaching. ISSN 
Murni Mahmud. (2018). Exploring Students' Politeness Perspective at the State University of Makassar. Journal of Education and Learning. Vol. 12, No. 1. ISSN.

S. L. Graham. (2007). Disagreeing to Agree: conflict (im)politeness and Identity in a Computer-Mediated Community. Journal of Pragmatic. Vol. 39. pp 742759.

Tri Rina Budiawati. (2018). Politeness Strategy Used by Obama in a Great Open Debate. Skripsi. Universitas Jember.

X. Jiang's. (2010). A Case Study of Teacher's Politeness in EFL Class. Journal of Language Teaching and Research. Vol. 3. pp. 655-661 